\title{
The 1753 Jewish Naturalization Bill and the Polemic over Credit
}

\section{Avinoam Yuval-Naeb}

\begin{abstract}
The polemic surrounding the 1753 Jewish Naturalization Bill was one of the major public opinion campaigns in Britain in the eighteenth century, as well as the most significant event in the history of Britain's Jews between their seventeenth-century admission and nineteenth-century emancipation. The bill proposed to offer Jews a private act of naturalization without the sacramental test. A costly and cumbersome process, the measure could have had only minor practical impact. Due to its symbolic significance, however, the bill ignited public clamor in hundreds of newspaper columns, pamphlets, and prints. What made it so resonant, and why was the opposition so successful in propagating opposition to the motion? It has been commonly argued that the entire affair was an instance of partisan conflict in which the Jews themselves played an incidental role. This paper throws light on the episode from an alternative perspective, arguing that a central reason for its resonance was that the discussion on the Jews evoked concerns with the expanding financial market and its sociopolitical implications. As Jews had by that time become emblematic of modern finance, they embodied contemporary anxieties about the economy, national identity, and their interrelations.
\end{abstract}

\section{INTRODUCTION}

Doubtless the most resonant event in Anglo-Jewish history in the two hundred years between Jewish readmission and emancipation was the polemic around the 1753 Jewish Naturalization Bill, or the Jew Bill, as it came to be known. The bill, intended to enable the naturalization of a small number of wealthy, foreign-born Jews by a private act of Parliament and without the prerequisite of taking the sacrament, sparked an unexpected public clamor. Dozens of newspaper articles, pamphlets, and caricatures were published in the six months between the bill's introduction in the Commons (May 1753) and its repeal (November 1753), and popular outcry persisted even after. The event's considerable resonance stood in apparent contrast to its minimal social and political implications, and this paper aims at answering the puzzle of this discrepancy by illuminating a dimension of the polemic that has been somewhat overlooked by historians who have explored it.

A crucial frame for understanding the event is the internal conflict within English and consequently British society over the place of finance in the social and political

Avinoam Yuval-Naeh is a postdoctoral fellow in the History Department and at the Vidal Sassoon International Center for the Study of Antisemitism at the Hebrew University of Jerusalem. He is grateful to Dror Wahrman, Sarah Mandel, Naomi Yuval-Naeh, and the editors and reviewers of the Journal of British Studies for their thoughtful comments on earlier versions of this paper. 
matrix after the so-called Financial Revolution. Contemporaries debated whether the post-1688 regime, its fortunes hinging increasingly on public finance, could avoid corruption in both the governors and the governed. The issue entailed conflictual conceptions of the state and its relations with its subjects, along with different concepts of both loyalty and liberty. It also contested two notions of the economic man and the relationship of property and personality. Advocates of the new politicaleconomic system praised the mobility of the individual enabled by an increasingly commercial society through interpersonal exchanges. In contrast, adversaries emphasized the autonomy that could only be acquired by stable property that made its owner independent of the men in government and thus able to resist the corruptive power of patronage, wrought to a great degree by new modes of finance. ${ }^{1}$

This enduring debate acquired new implications in the 1740s and early 1750s, with the escalation of the contest for global dominance among European powers. Imperial expansion, with the belligerent rivalries it entailed, required a corresponding increase in financing, which Britain attained by expansion of its national debt and a sophisticated financial system. At the same time, somewhat paradoxically, empire was hailed by nationalistic patriots as an emblem of national virility and a check against the decadence spread by a corrupted ruling elite, whose chief means for maintaining power, it was argued, was the public debt. ${ }^{2}$ Moreover, mid-century nationalistic imperialism was characterized by marked xenophobia that coupled the peril of "strangers" with that of administrative corruption. ${ }^{3}$ This point of view entailed another paradox, for in contrast to the nationalistic patriotic vision of empire, foreigners in fact played an important role in the imperial endeavor in the development and maintenance of commercial networks. These tensions were expressed in the question of citizenship, which had an important economic aspect and so became an unsettling matter in the imperial context of the eighteenth century.

This configuration lent Jews-both as an image and as social players-a new relevant significance. By the mid-eighteenth century, as shown below, they came to epitomize in the public imagery the prevalence of the new forms of finance. Consequently, this article suggests, the Jew Bill highlighted anxieties around the role of finance and its ramifications, making the polemic a channel through which existing ideologies found new shapes and vigor. The discussion of Jewish naturalization became-at different levels of explicitness - entwined with the dispute over the place and status of finance in the economic, political, and social systems.

The progress of the bill and the polemic has been well documented, and I offer here only a brief outline. ${ }^{4}$ As Jewish readmission to England was never formally endorsed, legal lacunae existed around Jews' status, and the intent of the limits posed upon them was ambiguous. Jews, on account of their not adhering to the

\footnotetext{
${ }^{1}$ John G. A. Pocock, Virtue, Commerce, and History: Essays on Political Thought and History, Chiefly in the Eighteenth Century (Cambridge, 1985), 48-49, 66-67, 107-110.

${ }^{2}$ Kathleen Wilson, The Sense of the People: Politics, Culture, and Imperialism in England, 1715-1785 (New York, 1995), 185-205.

3 Ibid.

${ }^{4}$ For the fullest treatment of the subject, see the classical study by Thomas W. Perry, Public Opinion, Propaganda, and Politics in Eighteenth-Century England: A Study of the Jew Bill of 1753 (Cambridge, MA, 1962); see also David S. Katz, The Jews in the History of England, 1485-1850 (Oxford, 1994); and Todd M. Endelman, The Jews of Britain: 1656 to 2000 (Berkeley, 2002), whose accounts are based on Perry's.
} 
Anglican faith, lacked certain civic rights—-such as being elected to and sitting in Parliament, holding office in municipal corporations, and entering universities-disabilities shared with Catholics and Dissenters who were the intended focus of the legislation. Moreover, about half of the Jewish community had been born outside England and hence endured alien disabilities, central among them the duties charged on traders, prohibition of owning land, and exclusion from colonial trade and ship ownership. It was this second set of restrictions that the Jewish petitioners sought to overcome. As the procedure of private denization did not exempt Jews from alien duties, the only remedy for their commercial inequality seemed an act of Parliament that would modify the demand for a sacramental test in order for Jews to obtain naturalization. ${ }^{5}$

In January 1753, Sephardi magnates approached the duke of Newcastle, Thomas Pelham, with a request for such a measure. The king's ministry, indebted to Jewish financiers for their financial support during the last Jacobite rebellion, was favorable towards the request. The bill was introduced in the House of Lords on 3 April, approved on 16 April, and first read in the House of Commons on 17 April. In spite of some opposition during its second reading (7 May), it passed and reached its third reading on 22 May. $^{6}$ At this point an expansive and acerbic public polemic began, yet royal assent was nevertheless given on 7 June, shortly before the parliamentary recess. The polemic raged widely throughout that time, most intensively in newspapers as well as in polemic pamphlets. Magazines and satirical prints played a lesser role, and the issue was also polemicized in non-print performances such as public speeches, club debates, and exhibitive behavior. ${ }^{7}$ Advocates of the bill gained a much smaller share of the discourse. When Parliament reconvened on 15 November, a bill of repeal was hurriedly enacted by the ministry, and public debate soon dwindled.

Scholars have grappled with assessing the episode. Some advocate that it is best explained in the context of English anti-Judaism, the bill providing an opportunity for the venting of deep-seated Judeo-phobic feelings. ${ }^{8}$ The mainstream explanation, however, promoted primarily by Thomas Perry in his still-valuable monograph, claims that the episode was first and foremost part of a long-standing division between Whig and Tory ideological traditions regarding foreign immigration and its political-economic implications-Whigs encouraging immigration as a demographic measure for fostering the English economy, Tories opposing it as an injury to national cohesion and "true" English prosperity. The question also involved another traditional Whig-Tory conflict, the diminution of church influence, for foreign-born immigrants were unlikely to be conformist in belief. According to this view, the episode was not a contest about Jews (who were merely an incidental

\footnotetext{
${ }^{5}$ Robert Liberles, "The Jews and Their Bill: Jewish Motivations in the Controversy of 1753," Jewish History 2, no. 2 (Fall 1987): 29-36.

${ }^{6}$ Perry, Public Opinion, 46-54.

${ }^{7}$ For a general survey on the opposition material see ibid., 89-95, 100-11, 117-21; Israel Solomons, "Satirical and Political Prints on the Jews' Naturalisation Bill, 1753," Transactions (Jewish Historical Society of England), no. 6 (1908-10): 205-33.

${ }^{8}$ Frank Felsenstein, chap. 8 in Anti-Semitic Stereotypes: A Paradigm of Otherness in English Popular Culture, 1660-1830 (Baltimore, 1999); Bernard Glassman, chap. 8, in Protean Prejudice: Anti-Semitism in England's Age of Reason (Atlanta, 1998).
} 
issue) but a political conflict, an opportunity for the out-of-power Tories to rally their cause against a powerful ministry in an election year. ${ }^{9}$

Both approaches have their weaknesses. Interpreting the episode as mainly an antiJewish expression is incompatible with the sudden decline of the discourse once the act was repealed and with the absence of physical violence during the episode. On the other hand, interpreting it as a manifestation of partisan political struggle does not explain why the issue of Jewishness was so powerful a tool in the political scene nor why the most minimal of all naturalization schemes in the eighteenth century evoked the most severe public response. ${ }^{10}$ Moreover, many of the opposition texts were without political orientation, sometimes denouncing the politicizing of the discussion per se. Perry's conclusion that the arguments of both sides had merely "incidental pro and anti-Jewish variations" that did not alter the nature of the polemic as a dispute over immigration is an exaggerated simplification that disregards what contemporaries actually said and read. ${ }^{11}$ On the contrary, the intensity of the polemic testifies to the cultural, social, and political significance bestowed upon the Jews either as symbols or as actual subjects. The downplaying of the Jewish element of the controversy seems somewhat artificial.

Considering these weaknesses, historian Todd Endelman has offered a synthesis of both approaches, suggesting that the clamor may have been triggered for political gains but that the feelings it brought to the surface were traditional derogatory images of the Jew that had become "part of England's cultural heritage."12 But what was this "cultural heritage" and why did it appeal specifically to mideighteenth-century Englishmen? Here we may find useful the framework offered by literary scholar James Shapiro in his influential work on the perception of Jewishness in the consolidation of English identity during early modernity. Shapiro argues that what made the controversy so acute was the vulnerability of Englishness at the time. For the bill's adversaries, Jews embodied otherness-racial, religious, social, and hence national; the polemic over their civil status thus became a shibboleth in a struggle of self-definition, a struggle much wider than the specific debate. ${ }^{13}$ Other scholars have followed this approach and explained the debate as an attempt to redefine English national identity at a time of crisis, emphasizing the way in which Jewish otherness worked as a marker around which English—or British— identity could crystallize. ${ }^{14}$

\footnotetext{
${ }^{9}$ Perry, Public Opinion; Katz, Jews in the History of England.

${ }^{10}$ The response was severe, compared, for instance, to the response to the 1708 "Act for Naturalising Foreign Protestants," which was also unpopular and was repealed three years after being enacted. See Daniel Statt, chap. 8, in Foreigners and Englishmen: The Controversy over Immigration and Population, 1660-1760 (Newark, NJ, 1995).

${ }^{11}$ Perry, Public Opinion, 178.

${ }^{12}$ Endelman, The Jews of Georgian England, 1714-1830: Tradition and Change in a Liberal Society (1979; repr., Ann Arbor, 1999), 89-90. See more generally 59-64 and 88-91.

${ }_{13}$ James Shapiro, chap. 7, in Shakespeare and the Jews (New York, 1996).

${ }^{14}$ Dana Y. Rabin, chap. 1, in Britain and Its Internal Others, 1750-1800: Under Rule of Law (Manchester, 2017); Rabin, “The Jew Bill of 1753: Masculinity, Virility, and the Nation,” Eighteenth-Century Studies 39, no. 2 (Winter 2006): 157-71; Rabin, "Seeing Jews and Gypsies in 1753," Cultural and Social History 7, no. 1 (March 2010): 35-58; Michael Ragussis, Theatrical Nation: Jews and Other Outlandish Englishmen in Georgian Britain (Philadelphia, 2012); Andrew Crome, "The 1753 'Jew Bill' Controversy: Jewish Restoration to Palestine, Biblical Prophecy, and English National Identity," English Historical Review 130, no. 547 (December 2015): 1449-78.
} 
Following that lead, this paper substantiates the somewhat general use of the term "identity" by focusing on the way in which the controversy grappled with the political economy. As it was an integral element in the matrix that constituted contemporary English identity, emphasizing it could help us understand some conflicts of English self-conceptions of the time and the ways in which notions of Jewishness were at play within them.

The aspect of the political economy within the polemic has been generally overlooked because the public controversy is conceived to have been stimulated by religious rhetoric. ${ }^{15}$ Perry has shown that what actually triggered the public clamor was a harsh opposition petition submitted to the Commons by the City of London on 21 May 1753, the evening before the bill's third reading, imbuing the debate with language of religion and nationality. ${ }^{16}$ The petition proved exceptionally influential and set the tone for the chief part of the oppositional discourse as well as for that of supporters of the bill, who had to reply to the denunciations. Henry Pelham recognized the petition as "the foundation of that seditious spirit afterwards propagated with so much industry through the whole kingdom" by giving "a religious turn to the dispute." 17 Accordingly, the petition divided the brief early phase of parliamentary discussion that focused on material questions, and the second and more substantial phase, which blended theological, scriptural, and historical ideas and prejudices about the Jews. ${ }^{18}$ Yet political-economic concerns in the public phase of the discourse were embedded within the religious language. The following two sections engage the theme of political economy in these two respective phases and the ways in which different perceptions of Jewishness and finance informed them.

\section{THE DEBATE IN THE HOUSE OF COMMONS: JEWISH FINANCE, THE NATIONAL DEBT, AND ENGLISH SOCIETY}

The main discussion in the House of Commons over the bill was held on 7 May and can be schematically analyzed as hinging on two interrelated issues: the effect of "Jewish finance" on the English economy (including its colonial network) and the

\footnotetext{
${ }^{15}$ An important exception is Jonathan Karp's contribution in The Politics of Jewish Commerce: Economic Thought and Emancipation in Europe, 1638-1848 (Cambridge and New York, 2008), chap. 3, which focuses on the conceptual uses of the Jews by political economist Josiah Tucker during and following the polemic. The current article, by tracing political-economic implications in the outpouring of a broad range of publications during the polemic, seeks instead to illuminate wide-ranging socioeconomic concerns and their projection on the public agitation over the bill, and consequently offers another dimension for understanding the broad engagement with this episode.

16 This was the second petition out of four (two in favor and two against the bill) presented to the House of Commons on 21-22 May 1753. See Perry, Public Opinion, 54-62.

17 Taken from the discussion in the Commons on the repeal of the Jew Bill on 27 November 1753, in William Cobbett, The Parliamentary History of England, vol. 15 (London, 1813), 144-45. See also Horace Walpole's reflections in the same meeting; ibid., 152.

18 This is not to say that religious themes and arguments were totally absent in initial parliamentary discussions, but these were raised mainly pertaining to the capability of the establishment to contain religious differences.
} 
wide-ranging impact of the national debt. ${ }^{19}$ Both sides agreed on the assumption that Jews were mostly employed in commerce and finance, not in manufacture. What they disagreed about was the contribution, or damage, that naturalization of Jews-conceived to trigger the introduction of Jewish immigrants-would cause. The bill's supporter Lord Dupplin (Thomas Hay), a pivotal figure in the administrations of Walpole, Pelham, and Newcastle, argued that the Jews by their extensive global correspondence and their "great command of money" promoted the commerce of every country in which they dwelt. ${ }^{20}$ All the bill's supporters argued for the profound contribution Jews had made to both commerce and government finance in England since their readmission to the country. ${ }^{21}$ On the other hand, John Barnard, a merchant and former mayor of London and a fierce opponent of the bill, argued that because Jews were never "bred to be manufacturers or mechanics or indeed to any laborious employment," their integration within English society would not result in a contribution to English commerce but rather a quick takeover of it. Jews were especially diligent in "recommending one another and in playing into the hands of one another," and they would hinder any Christian from gaining profit from either foreign or domestic trade. They would become England's only merchants, leaving "the laborious part of all manufactures and mechanical trades to the poor Christian," of whom they would be masters. ${ }^{22}$ It is telling that the point debated was not Jews' economic propensity but whether boosting the financial sector would enhance English productivity. Proponents of the bill encouraged bringing capital into the system as a means of augmenting commercial and productive capacities, while adversaries implied that the kernel of productivity was labor, and that finance was not included in that category.

Schematically, the conflicting stances promoted contradictory conceptions of economic dynamics. Barnard's view of Jewish monopolism relied upon a conception of the economy as a restricted and fixed system that could not be developed beyond given limits set by manufacture, finance, and commercial connections. Once all conditions were fulfilled to the maximum - as he believed was presently the case in England-bringing in additional economic agents would result in reduced profits to the English in favor of foreigners (Jews). ${ }^{23}$ In the other camp, Nicholas Hardinge, secretary to the Treasury and a Cambridge classical scholar, neo-Latin poet, and lawyer, argued conversely that the economic system was open, and that even in well-developed commercial countries such as England (perhaps especially in such countries), "new men will probably make new experiments, and by new experiments, new channels of trade may be discovered, through which new and additional quantities of our manufactures may flow to a foreign market." Here the Jews entered the

\footnotetext{
${ }^{19}$ For a general analysis of the debate, see Perry, Public Opinion, 78-89. For a survey of the theme of colonial commerce in the parliamentary debate on the Jew Bill, see Sheldon J. Godfrey and Judith C. Godfrey, Search Out the Land: The Jews and the Growth of Equality in British Colonial America, 17401867 (Montreal, 1995), 52-54.

${ }^{20}$ Cobbett, Parliamentary History, 14:1376.

${ }^{21}$ Ibid., 1378, 1386-87, 1402.

${ }^{22}$ Ibid, 1393. A similar threat was expressed by Nicholas Fazakerley, long-time MP for Preston and an ardent anti-governmental politician; ibid., 1409.

${ }^{23}$ Ibid., 1390-92. Barnard proposes that precisely because of these conditions, Jews might prove beneficial in countries that had already set their trade but still lacked either capital or commercial connections. On this point, see Karp, The Politics of Jewish Commerce, 85.
} 
picture, for no people were supposed "more capable, or more ready than the Jews, to make these new experiments, because of their great propensity to trade, and because of the curse that attends them"-namely that Jews were deprived of a national land. ${ }^{24}$ Barnard and Hardinge, as representatives, may have held a similar view of Jewish commercial inclinations, yet the combination of that view with a contrary economic framework yielded contrary judgments. ${ }^{25}$

The other theme, which was debated more expansively, was the national debt and its link with Jews. Begun in the 1690s to support the expanding military expenditure, the debt was consistently growing with the almost constant warfare in which England (later Britain) was engaged. Although it was thought that there was no other means than debt of financing the military's needs, many believed that Britain would never be able to fully pay it off. The debt became a crucial frontline between the Whig government and the opposition, which saw it as a national disaster and a source of corruption by supplying the government with limitless funds. Moreover, it was argued that the government became dependent on its investors' belief (or disbelief) regarding its capacity to pay back its debt, making the fluctuating value of public stock the index of the government's stability or instability. This speculative fantasy transformed government-citizen relations, and by implication those between all citizens, into relations between debtors and creditors. ${ }^{26}$ While opposition members perceived the debt as anti-patriotic, government-inclining members saw it as a responsible fiscal method and a true national scheme without which Britain would lose its power.

The opposition's anxiety over the national debt was well articulated in the speech in the Commons by the Tory member of Parliament for Preston, Nicholas Fazakerley. Concluding a long historical reflection on the Jews in England, Fazakerley identified the Glorious Revolution as a crucial moment of change. For although the Revolution freed the nation from bigotry and tyranny, it instilled a new form of subordinationthe raising of governmental funds on interest. This new fiscal measure had been "so favourable for the Jews" but "a most unfortunate custom for the nation," as it resulted in the setting up of stockjobbing-the contemporary term for fraudulent financial schemes. Jews and other foreigners "were invited by act of parliament to practise that trade of usury upon the state," a trade particularly abused by the Jews who "by Edward the lst's law ... had been forbid to practise upon the subject."27 The influence of the debt on the state was seen as destructive. Since its introduction, England has been "like a young extravagant heir, who proportions his expence not to his income, but to his credit, without plaguing himself with the troublesome thought how the money he borrows is to be repaid." 28 Public credit had not only ruined national responsibility but also "encouraged and enabled our ministers to engage

${ }^{24}$ By being globally dispersed, Jews had a detailed knowledge of changing supplies and demands. See Cobbett, Parliamentary History, 14:1397.

${ }^{25}$ For earlier versions of the Whig-Tory debate on the open/closed nature of the economic system, see Steven Pincus, "The State and Civil Society in Early Modern England: Capitalism, Causation and Habermas's Bourgeois Public Sphere," in The Politics of the Public Sphere in Early Modern England, ed. Peter Lake and Steven Pincus (Manchester, 2007), 213-31; see also Peter Lake and Steve Pincus, "Rethinking the Public Sphere in Early Modern England," Journal of British Studies 45, no. 2 (April 2006): 270-92.

${ }^{26}$ Pocock, Virtue, Commerce, and History, 110-12.

${ }_{27}$ Cobbett, Parliamentary History, 14:1405.

${ }^{28}$ Ibid., 14:1405. 
us in needless wars upon the continent, or to continue those wars longer than the interest of this nation required." 29

To this main claim, other arguments were added. William Northey maintained that as Britain was not in a state of war that demanded a large budget, there was no sense in offering naturalization at that moment. Even in such a case, he added, "we should not, I think, part with our birthright for nothing." Barnard claimed that Jewish investors would adhere not to the public interest but merely to their own profit, and hence would lend money to the state without the necessity of naturalization. ${ }^{30}$ The question of the nature of the loyalty to the state and society would recur throughout much of the debate. However, not only the loyalty of the Jews was in question but also the loyalty and interests of investors in public debt in general, both English and foreign.

The association between the economic nature of the Jews and Britain's destructive debt reached a peak in the third reading of the bill in the Commons on 22 May. After the four petitions were presented, the opposition presented a motion to postpone the debate for a month. That timing would slide into parliamentary recess, meaning the bill would be killed. The only contribution to the discussion that we know of was by opposition member John Perceval, the earl of Egmont. His powerful speech conflated Anglo-Jewish history, economic anti-Jewish views, and criticism of current fiscal policy:

The trade of the Jews, as it appears by the oldest of our histories, and the earliest records both here and in other countries, was usury, brokerage, and jobbing, in a higher or a lower degree. By this traffic, in former ages, they distressed and ruined the Christian subjects in such numbers every where, as to draw down upon them from time to time the resentment of all nations, and in this traffic they have improved so far in this age, as now to ruin whole kingdoms instead of individuals, by aiding ministers to beggar the states they serve, by which traffic also they have greatly aided to plunge this nation into a debt of near eighty millions. ${ }^{31}$

Lord Egmont identified the Jews' economic persona as potentially devastating for the nation. One instance of such an affliction, his speech implied, was the establishment of the national debt through a Jewish conspiracy. Jews could never be incorporated in the nation on an economic basis, for they were not capable of "real" and "honest" commerce. This was proved, he argued, by the history of Jews in England since their readmission, where in spite of their wealth and the greatest commercial opportunities, they did not carry on any substantial trade. All the fortunes made by Jews in England had been acquired through "contracts, subscriptions, commissions, and correspondencies, and all kinds of jobbing with the necessities of the public in the late war." Their proposed naturalization therefore would lead to "no important addition of property to this kingdom; to no possible increase of strength; to no improvement in manufactures; to no extension of commerce." 32

The supporters of the bill painted a contrary picture of the Jews, the debt, and governmental policy. Robert Nugent, a canny, Irish-born politician having lately reconciled

${ }^{29}$ Ibid., 1411-12. The threats posed by the new political-economic system and the centrality of Jews in it were recurrent themes in the press and pamphleteering in the subsequent months.

${ }^{30}$ Ibid., 1394, 1366.

${ }^{31}$ Ibid., 1424.

32 Ibid., 1424. On other aspects of Lord Egmont's speech, see Perry, Public Opinion, 65-67. 
with the Pelham ministry, claimed that, since the Glorious Revolution, the Jews had been extremely useful to the state "by supplying our government with large sums of money for carrying on expensive wars we have been necessarily engaged in."33 $\mathrm{He}$ specifically emphasized Jewish financial aid in preserving of the public credit during the Jacobite rebellion of 1745 as an indication of their loyalty and contribution. Advocates of the Jewish cause not only argued for the legitimacy of the Jews' contributions but for the legitimacy of the means itself: the service to the state by maintaining its debt.

Advocates also argued that the Jew Bill would allow the domestic economy to benefit from much of the annual dividends paid on the debt, currently spent abroad, sometimes "among our most avowed enemies." Pelham contended that Britain was losing $£ 1-2$ million of dividends annually sent abroad to investors who would prefer to live in Britain. ${ }^{34}$ The clearest expression of the issues at stake was given by Nicholas Hardinge, who emphasized not only the Jews' financial and commercial contribution but also the national and constitutional importance of the debt. For it was the public credit, much advanced by Jews, "to which we in a great measure owe the preservation both of our religion and liberties."

Tellingly, just as some opponents of the bill attributed the establishment of the national debt, not only their current investment in it, to the Jews, so did proponents, including Hardinge. ${ }^{35}$ This was an anachronistic projection of the relative prominence of Jewish stockholders of government loans from the early and mid-eighteenth century back to the period of its establishment in the 1690 s. $^{36}$ It is a handy illustration of the dynamic of the parliamentary debate in its political-economic perspective: adversaries agreed upon the "facts," even the fabricated ones, yet disagreed about their significance. The disagreement derived to a great degree from their wider perception of economic dynamics and the role of finance in the modern political economy of a commercial state. These contrasting perceptions entailed distinct notions of loyalty and productivity, for where one side saw a benefit, the other identified deterioration. These lines of engagement in the Commons debates provided the contours for the public polemic that soon spread and took on new life.

\section{RELIGION AND POLITICAL ECONOMY IN THE PUBLIC OPPOSITION DISCOURSE}

As noted, the public debate was ignited by the City's petition coinciding with the third reading of the bill. While the religious rhetoric indeed became prevalent from that point onward, political-economic concerns were not discarded but

${ }^{33}$ Cobbett, Parliamentary History, 14:1386-87.

${ }^{34}$ Apparently Pelham did not mean only Jews. Ibid., 1413. See also Lord Dupplin’s speech, ibid., 1376, 1378.

${ }^{35}$ Ibid., 1402.

${ }^{36}$ Out of the first 1,272 shareholders of the Bank of England in 1694, about seven were Jews, their largest subscription being $£ 1,500$ and their second-largest $£ 1,000$, out of 347 subscribers of $£ 1,000$ $£ 5,000$ and 44 of over $£ 5,000$. By the 1710 s, however, Jewish investors figured in the top section of stockholders (ten out of the seventy-four holders of subscriptions of $£ 5,000$ and more), a trend that increased by mid-century. See J. A. Giuseppi, "Sephardi Jews and the Early Years of the Bank of England," Transactions (Jewish Historical Society of England), no. 19 (1955-1959): 53-63; Dickson, The Financial Revolution in England: A Study in Development of Public Credit, 1688-1756 (New York, 1967), 253-64. 
rather incorporated. This convergence took several forms. Opposition writers often linked religious decline with economic misconduct and luxury. This well-established theme, commonly employed by critics of both the political system and society at large, was enhanced around mid-century, as Kathleen Wilson aptly illustrates. ${ }^{37}$ Yet its use in the context of the Jew Bill was not merely a reiteration.

The notion of religious decline prompted by the material lure of financial economy was promoted by writers across the opposition spectrum and most blatantly expressed by the London Evening Post, the leading organ opposing the bill. "Old England," a frequent letter-writer to the paper, asserted that the bill sought to further subordinate the nation to "the baneful Power of Money," inciting ministers to rely on the power of money for gaining political influence and to bypass the constitutional power of the Commons and the sentiments of the people. The result would be not only the subordination of the English to the Jews and the corruption of the political system but also damage to religion- "Religion, Conscience, Honour, and Publick Good, laugh'd at as Cant and Foible." The letter concluded with a call to fellow "Britons, Christians and Protestants" to wake up, for the Jews were at the gates, "coming for the Keys of your Church doors."38 Likewise, "Timothy Freeman" stated that Jews would buy with their money the "very souls" of English people. ${ }^{39}$ Other writers conflated blasphemy and extortion, depicting advocates of the bill as favoring pecuniary profit even when the implication was the undermining of religion: "Jew-like, we are to mind nothing in this Bill but Trade. Our God and our Religion Are to be quite out of the Question, and Money, ALMIGHTY Money, is to be the Basis of our State." 40 The power of money as opposed to religion was expressed in recurring allegations that Jews intended to overtake Christianity with their money. One writer imagined a dialogue between two Jews, Zimri and Shylock:

Why surely, Friend Shylock, thou can'st guess at the Cause / Ha'n't we bought a whole Nation, Religion and Laws? / A Land overflowing with Milk and with Honey / Where their Christ and their God may be bought with our Money? ${ }^{41}$

By this view, the prospective Jewish takeover evolved from the spread of luxury and its impact on English society, which had enabled the presenting of the Jew Bill in the first place. The Zimri-Shylock column in London Evening Post, for instance, was followed by a comment on a "Deluge of Luxury overspreading all Ranks, Sexes and Ages, [which] raises the Indignation of the Few that remain still on firm Ground."42 A month later, another London Evening Post writer, identified as "a Dissenter," argued with "a religious horror" that the Jews took advantage of the "Luxury and Corruption of the Times [in order to] purchase to themselves such Privileges as

${ }^{37}$ Wilson, The Sense of the People, 185-205; Bob Harris, "The London Evening Post and MidEighteenth-Century British Politics,” English Historical Review 110, no. 439 (November 1995): 113256 , at 1144 .

${ }^{38}$ London Evening Post (hereafter LEP), 22-24 May 1753.

${ }^{39}$ LEP, 28-31 July 1753.

${ }^{40}$ LEP, 28-30 June 1753.

${ }^{41}$ LEP, 13-15 September 1753.

42 Ibid. 
have hitherto been constantly denied to as good Subjects as any in the Nation." ${ }^{\prime 43}$ "John Christian" related religious decline to a general corruption of manners and claimed that the Jews had an extensive destructive influence on the minds of many by their immoral economic practices. ${ }^{44}$ Accordingly, adversaries concluded, the present base economic conduct would provoke godly wrath on Britain. The signs were already apparent: an earthquake in Cheshire was attributed to the bill's enactment. ${ }^{45}$ Set on this course, English society was doomed to share in the Jewish curse of landlessness; hence it should be every Englishman's wish that godly punishment of the Jews would not be delayed before they obtained too much power. "John Christian" closed his letter, "Let G[ideon]'s Gold, and old sly Shylock's Purse, Instead of Blessing, prove to them a Curse."46

The connection between Jews' corrupting economic conduct and their conflict with Christianity was promoted in opposition pamphleteering as well. Reverend William Romaine, the most prominent clerical writer against the Jew Bill, summarized Anglo-Jewish history: what a "prevailing Engine the Jews Money was, and how successful they have been in trusting their Cause to its Influence." That money, he argued, explained not only the introduction of Jews into England by both William the Conqueror and Cromwell but the whole of Jewish history, enduring "by the self same Money-Engine-preferred by too many, who call themselves Christians, even to Christ himself and Christianity." 47 The claim that Jews did not endeavor to convert others, Romaine said, did not take into account that Jews' first priority was making money, which had become their worshipped idol. Economic conduct was profoundly interwoven in the religious life of the Jews and hence would similarly affect England at both economic and religious levels. 48

The conflation of the religious and the economic was reinforced by frequent use of a biblical style, images, and history. An illustrative example is a piece published in Read's Weekly Journal, under the title "The 1753rd Chapter of the JEWS," which recounted the history of the Jews in England in a pseudo-biblical manner. The Jews were depicted as hard-hearted vagabonds, worshipping the Devil in the form of money. They found England suitable for their purposes, as its people were "given to foolish Bargaining." "Peradventure," the Jews understood, "they will want our Silver and Go'd; then shall we have their Lands, and become their Lords to rule over them." Consequently, they "trafficked greatly, and supplied the Wants

${ }^{43}$ LEP, 30 October-1 November 1753.

${ }^{44}$ LEP, 25-27 October 1753. See also the letter of "John Christian" in LEP, 28-30 August 1753, arguing that it was "for want of a due Regard to Religion and to a Depravation of Manners that such an Act could have ever been thought upon." In a similar vein, see the Westminster Journal, 9 June 1753, reprinted in A Collection of the Best Pieces in Prose and Verse against the Naturalization of the Jews (London, 1753), 43-44.

${ }^{45}$ See LEP, 19-21 June 1753, 22-24 May 1753, 26-28 July 1753.

${ }^{46}$ LEP, 25-27 October 1753.

${ }^{47}$ William Romaine, An Answer to a Pamphlet, Entitled, Considerations on the Bill to Permit Persons Professing the Jewish Religion to Be Naturalized... . (London, 1753), 5. Romaine's account of Jewish history relies on William Prynne, Short Demurrer, pt. 1 (London, 1656). See also An Appeal to the Throne against the Naturalization of the Jewish Nation... . (London, 1753), 5-6.

${ }^{48}$ Romaine, Answer to a Pamphlet, 39-40. It is likely that Romaine also contributed letters to LEP focusing on the religious aspects of the polemic. On this attribution, see Harris, "The London Evening Post," 1136-38. 
of the Extravagant and Proud, and increased in Riches and Power." At that point a leader was erected among the Jews-Shylock-who promised them to accomplish the overtaking of England, and the Jews deposited their wealth in his hands for that end. The story stopped there, to be continued (though it never was), implying the unclear future of the Anglo-Jewish conflict. ${ }^{49}$

A recurrent motif was the association of the Jewish cause with the Golden Calf. "Britannicus" asserted that courting the Jews for their riches was worship of the Golden Calf, and "Civis Londinesis" stated that there were few people who had "not yet fallen down and worshipped the GOLDEN IMAGE" set in place by the Pelham faction. ${ }^{50}$ In another mock-biblical account, the London Evening Post stated that only a few people "had not kissed the Golden Calf, nor bowed their Knees to the Idol of the Times." 51 The Connoisseur, a satirical London weekly produced by George Colman and Bonnell Thornton and inaugurated just as the Jew Bill was repealed, expressed much concern in its first issues regarding the bill and the Jews. In a letter allegedly written by a Jewish man of taste buying pieces of art on a trip to the Continent, the writer recounted his acquisition of a picture titled The Elevation of the Golden Calf, which he intended to set up in the Royal Exchange "as a typical representation of myself, to be worshipp'd by all Brokers, Insurers, Scriveners and the whole fraternity of Stock-jobbers. ${ }^{\prime 52}$

Perhaps the most pervasive religious motif in the opposition discourse was that of circumcision. The opposition propagated the threat that the Jew Bill would result in the Jews taking over England and forcing the circumsizing of all males. In one sarcastic remark, the bill was referred to as "the Law in favour of the Circumcision." 53 One could dismiss this obsession as whimsical, as Perry argues; yet broadening the perspective to the long-term historical occurrence of the theme reveals an early modern English preoccupation. ${ }^{4}$ That this motif was employed for political aims by opposition polemicists does not exclude its prevalent cultural significance. Consequently, several scholars have explored its meaning in the polemic, emphasizing the conflation of masculinity, dignity, and power as the fundamentals of a consolidating British identity against which Jewish identity was posed as a foil. ${ }^{55}$ Following this approach, I argue that an important aspect of the cultural work done by that

${ }^{49}$ Read's Weekly Journal, 28 July 1753. For another example, see LEP, 24-26 July 1753.

${ }^{50}$ LEP, 24-26 May 1753, 26-28 July 1753, 14-16 August 1753.

${ }^{51}$ LEP, 18-20 October 1753.

52 Other pictures purchased included Peter Denying His Master and Judas Betraying Him for Thirty Pieces of Silver, designed as presents to bill-supporting bishops. See Connoisseur 1, no. 2 (February 1754): 9-11. The association of English people with Judas, favoring base money over their religion, was common among other writers as well. See, for example LEP, 19-21 July 1753.

${ }^{53}$ Public Advertiser, 26 November 1753. Examples of this motif are abundant, some of which can be found in the references in note 54 below.

${ }^{54}$ See, for example, Roy S. Wolper, "Circumcision as Polemic in the Jew Bill of 1753: The Cutter Cut," Eighteenth-Century Life 7, no. 3 (May 1982): 28-36; Felsenstein, Anti-Semitic Stereotypes, 137-47; Shapiro, chap. 4, in Shakespeare and the Jews, 111, where he relates English emphasis on circumcision to the libel of ritual murders.

${ }^{55}$ G. A. Cranfield, “The 'London Evening-Post' and the Jew Bill of 1753," Historical Journal 8, no. 1 (January 1965): 16-30, at 24; Wolper, "Circumcision as Polemic"; Rabin, chap. 1, in Britain and Its Internal Others, 1; Rabin, "The Jew Bill of 1753"; Madge Dresser, "Minority Rites: The Strange History of Circumcision in English Thought," Jewish Culture and History 1, no. 1 (August 1998): 72-87; Caroline Gonda, "Queer Doings in Oxford: The Christian's New Warning Piece (1753)," in Queer People: 
concept was achieved by an association between circumcision and finance, which was part of the more general conflation of religion and economy. Circumcision was a compelling image to depict the danger of the Jew Bill, I suggest, because the eighteenth-century image of the man of finance was of a feminized economic creature controlled by his passions and fantasies-very different from the image of the conquering man of finance of the modern era. ${ }^{56}$ The circumcised Jew epitomized not only physical unmanliness but also economic effeminacy. What lent it its force was the co-occurrence of the polemic within a tense nationalistic atmosphere in which perceived threats to the nation-political, military, and economic - were often imagined as both the result and the reflection of "feminization." 57 While the fear of phys$i c a l$ circumcision by the Jews was apparently absurd, its symbolic aspect-economic circumcision-could be seen as an imaginary manifestation of existing socioeconomic anxieties. The long-lived prejudice against Jewish circumcision intersected with an uneasy and highly gendered social discourse on socioeconomic matters, producing accordingly effective propaganda.

Opposition texts frequently depicted circumcision as a Jewish demand in exchange for financial support. "Timothy Freeman" in the London Evening Post remarked that "for Money shal [they] circumshise us, if they plese," 58 and MPs supporting the bill were mocked as being on their way to circumcision by seeking Jewish financial support. ${ }^{59}$ Coin clipping, a crime Jews were traditionally accused of, was also associated with circumcision, ${ }^{60}$ and opposition polemists made keen use of it. Thus, in the satirical song "The Pork of Old Engand," Jews of the day were compared to their medieval ancestors: "In brave Edward's days they were caught in a gin, / For clipping our coin, now to add sin to sin, / As they've got all our pelf, they'd be clipping our skin. / Those foes to the pork of Old England."61 As by this time Jews were no longer blamed for coin clipping, the writer created an alternative continuity

Negotiations and Expressions of Homosexuality, 1700-1800, ed. Chris Mounsey and Caroline Gonda (Lewisburg, 2007), 261-73.

${ }^{56}$ Literature on the motif of gender in the discourse on commercialism is vast. See, for example, Pocock, Virtue, Commerce, and History, 114; Catherine Ingrassia, "The Pleasure of Business and the Business of Pleasure: Gender, Credit, and the South Sea Bubble," Studies in Eighteenth-Century Culture 24, no. 1 (1995): 191-210; Natasha Glaisyer, "A Due Circulation in the Veins of the Publick': Imagining Credit in Late Seventeenth- and Early Eighteenth-Century England," Eighteenth Century 46, no. 3 (Fall 2005): 277-97; Paula R. Backscheider, "Defoe's Lady Credit," Huntington Library Quarterly 44, no. 2 (Spring 1981): 89-100; Kimberly S. Latta, "The Mistress of the Marriage Market: Gender and Economic Ideology in Defoe's 'Review," English Literary History 69, no. 2 (Summer 2002): 359-83; E. J. Clery, The Feminization Debate in Eighteenth-Century Britain: Literature, Commerce and Luxury (Houndmills, 2004).

${ }^{57}$ Clery, The Feminization Debate in Eighteenth-Century Britain; Wilson, The Sense of the People, 185205.

${ }^{58}$ LEP, 28-31 July 1753.

${ }^{59}$ See, for example, The Christian's New Warning Piece: Or, a Full and True Account of the Circumcision of Sir. E.T. Bart. As It Was Perform'd at the Bear-Inn in the City of Oxford, on Saturday Last... . (London, 1753); LEP, 4-7 August 1753; Wolper, "Circumcision as Polemic."

${ }^{60}$ For a survey of accusations of Jews of coin clipping in Middle Ages, see Joe G. Hillaby and Caroline Hillaby, The Palgrawe Dictionary of Medieval Anglo-Jewish History (Houndmills, 2013), 103-9. Most notable was the coin-clipping crisis in 1278, when King Edward I ordered the arrest of hundreds of Jews suspected of coin clipping. More than three hundred were executed.

${ }^{61}$ LEP, 26-28 July 1753. 
between past and present: having already commandeered all English money and in no need of clipping coins, Jews were turning to clipping other objects.

Notably, circumcision played a part in the polemic in the frequent use of the biblical story of Dinah and Shechem (Genesis 34) as epitomizing the threat to English society. The most elaborate adaptation of the story is found in a London Evening Post column, "The 34th Chapter of Genesis," which conflated the biblical story with current events. English girls triggered the affair when they visited Jewish girls in their synagogue. There they were seen by the "Sons of Gid[eon], of Shylock, of Mend[ez], Fran[co], and Salv[ador]," who lay with them by force and defiled them. Consequently, the Jewish financiers, the boys' fathers, approached "the Pelh[ami]tes," and asked them for "your Virgins for Wives" in exchange for "so many Bank Notes and Gifts." Up to this point, Britons were equated with the biblical Jews, and the Jews took the role of the Canaanites. The roles inverted at the point when the Jewish magnates demanded that the Britons be circumcised in order to marry Jewish girls. If not, they threatened to withdraw their money from the funds, and be gone. The Pelhamites ordered all subjects "to be circumcised, to depart the Land, or to be deliver'd over as a Prey to the Israelites." Gideon and Shylock gathered the Jews at the Exchange and announced the agreement. And on the third day, "whilst [the Britons"] Private Parts were sore," the Jews "took their Swords, and slew every Male of the Britons," including the Pelhamites. ${ }^{62}$

The opposition's conflation of religion and the economy paralleled the broad theological division of Judaism and Christianity with the conflict between the apparently corrupting contemporary speculation-based economy and the traditional stable commercial economy. This pattern is illustrated in a letter by "Britannicus," a writer previously mentioned, who was a leading voice in the London Evening Post in the 1750s and has been identified by Bob Harris as Paul Whitehead, a satirist and poet strongly connected to opposition politicians. ${ }^{63}$ Presuming that states should adopt religious structures compatible with their political-economic structures, "Britannicus" maintained ironically that only Judaism could fit England as a religion. As "Gold is the sole Mover of our grand political Machine," with no regard to the future of society nor tradition, "would not therefore the Naturalization of the Hebrew Race greatly strengthen and confirm our political System?” While the present politicaleconomic conduct was perfectly in accord with Jewish views, gold being "all that the Jews expect or desire of God," as evident in the Old Testament, "the Christian Religion is very inconvenient for a commercial People; it so cramps Men in Pursuit of their worldly Interests, and raises within their Breasts that frightful Chimera call'd Conscience." Appealing for replacing the national religion, "Britannicus" assured his audience that the shift would not be very noticeable, as "every Man, who calls himself a Christian, but acts only upon the Principles of worldly Interest, is indeed, tho' uncircumcised, already a Jew." "Honestus," in Read's Weekly Journal,

${ }^{62}$ LEP, 18-20 October 1753. The theme is frequent in many of the sources. A telling instance is found in the anonymous The Christian's New Warning Piece, in which the rabbi preaches on the story of Dinah before the circumcising of E. T. Bart (based on the Whig candidate for Oxfordshire, Sir Edward Turner). For a broader view of the uses of the story in eighteenth-century English social discourse, see Rabin, chap. 1, Britain and Its Internal Others.

${ }^{63}$ Harris, "London Evening Post," 1145-47.

${ }^{64}$ LEP, 26-29 May 1753. 
contended that commerce depended upon Scripture, which regulated all personal and social practices. As Scripture itself highlighted the unbridgeable breach between Jews and Christians, both in conduct and beliefs, it strictly forbade communication between Jews and Christians in matters of commerce and commercial norms. ${ }^{65}$ An anonymous pamphleteer argued that the basic notion behind the bill contradicted the political economy of Christianity; hence in no way could it be seen as a measure for promoting the conversion of Jews to Christianity, as proponents of the bill repeatedly claimed:

The first Step to Christianity is to deny the World and be above it: And when I see a Set of People anxious for the Goods of this Life, seeking Settlements here, desirous of joining House to House, and calling Lands after their own Names, I cannot imagine their Views are any Thing but worldly... consequently gratifying their Desires would be hardening them in their Apostacy. ${ }^{66}$

Another anonymous column in the London Evening Post claimed, again ironically, that naturalizing rich Jews could do England no harm. The bill "cannot hurt Trade in general, because the Jews are not general Traders; and what they do in the City is not Trade, nor any thing like it." Rich Jews were "entirely in the Money Way, concerned in the Stocks, as State-Brokers and Jobbers," an economic arena that excluded Christians, who had "some strange scruples about the Lawfulness of this Possession." This incommensurability of Jewish and Christian trade, the writer comically argued, made the Christian trade immune to Jewish damage. The rich Jews traded only in stockjobbing, and stockjobbing was the plundering of the public; but because a Christian could not plunder the public, consequently he could not trade in stocks. ${ }^{67}$ The piece was whimsical, yet to achieve its point it both conveyed and assumed that the audience would conceive a distinction between Jewish and Christian economies, equating trade in credit with Jews.

The conflation of economy and religion, as exemplified in these excerpts, sought to depict Judaism and Christianity as not only distinct religions but also as two contradicting economic ethics. This important and powerful thrust of the oppositional discourse was not pursued by all opposition writers, however. Some, with whom I do not deal here, did not focus on economic matters at all but only on religious issues. Still others who did focus on the economic aspect expressed a profoundly different attitude to the relation between economy and the Jews, and between economy and religion. It would thus be wrong to depict the two camps solely in binary terms of liberalism and tolerance versus conservatism, stagnation, and narrow-mindedness. Certainly, the prevailing tone in opposition propaganda was vehemently prejudicial, relying heavily on traditional anti-Jewish libels. However, few opposition voices expressed a complex set of socioeconomic assumptions and perceptions of Jewishness. Although all connected the Jews intrinsically to the question of the financial

${ }^{65}$ Read's Weekly Journal, 20 October 1753.

${ }^{66}$ Remarks on the Reverend Mr. Tucker's Letter on Naturalizations (London, 1753), 26. The writer alludes to biblical phrases castigating Israel for its lack of social solidarity: "calling Lands after their own Names" (Psalm 49:11), and "joining House to House" (Isaiah 5:8).

${ }^{67}$ LEP, 21-23 August 1753. 
system's functioning, some expressed qualified approval of the system and only denounced Jews' influence upon it.

A central point of division regarding Jewish economic behavior was the question of its historicity. Was the Jewish propensity to finance, and the Jewish economic nature in general, innate or changeable? While adversaries commonly depicted an essential link between Jews and finance, and the new financial system as Jewish in nature, advocates argued that it was through external circumstances that Jews came to occupy typical trades in what can be termed the circumstantial explanation of the "economic Jew." 68 This dimension of the polemic was part of a broader context of changing conceptions in the eighteenth century of difference and a developing preoccupation with classification. Are there innate differences between peoples or races, and what are the elements that constitute them? With the decline of the explanatory force of scriptures from the latter part of the seventeenth century in engaging with these questions, secular racial explanations took their place. The Jew Bill polemic was an effective platform for developing images of both bodily traits and inherent social features of Jewishness. ${ }^{69}$

Tellingly, some opponents employed the pro-Jewish circumstantial reasoning to attack the bill. For if the socioeconomic limits on Jews were removed, they claimed, Jewish economic uniqueness would diminish, and hence their expected contribution hailed by advocates would never materialize. ${ }^{70}$ Moreover, some opposition writers accepted, at least outwardly, the importance of the national debt for consolidating British power, and they used the advocates' own arguments to illustrate the bill's futility. A writer in Read's Weekly Journal, for example, argued that Jews must be excluded from investing in land (as the bill allowed), so that "upon any Emergency" their money would be liquid for backing the state. ${ }^{71}$ In contrast, other opposition writers disputed there could be any favorable outcome of an influx of foreign (Jewish) capital. A letter to the Public Advertiser in mid-November argued that the whole polemic had been conducted wrongly; had the opponents focused seriously

\footnotetext{
${ }^{68}$ Such argumentation can be traced to early modern Jewish apologetics, the most influential representative of this voice being Rabbi Simone Luzzatto, who had great impact among both Jewish and nonJewish thinkers. See Karp, The Politics of Jewish Commerce, 21-27. The central advocate of the bill, "Philo-Patriae," expressed that line clearly: "Their Avarice, or Love of Money, may be accounted for, from the restrictive Laws in many Places, which confined them to Traffick and Gain, the necessary Consequence of which has been, that enriching themselves became their chief View in worldly Affairs; but that, where in free Countries they have had different Educations and Views, we find them capable of thinking like other Men." Philo-Patriae, Further Considerations on the Act to Permit Persons Professing the Jewish Religion, to Be Naturalized by Parliament. In a Second Letter from a Merchant in Town to His Friend in the Country... . (London, 1753), 6-7.

${ }^{69}$ For the centrality of visual images in constructing Jewish racial difference during the polemic, see Isaiah Shachar, "The Emergence of the Modern Pictorial Stereotype of 'the Jews' in England," Studies in the Cultural Life of the Jews in England, ed. Dov Noy and Issachar Ben-Ami (Jerusalem, 1975), 33164; Rabin, "Seeing Jews and Gypsies in 1753." For a broad view on the construction of differences in the eighteenth century, see, for example, Richard Popkin, "Medicine, Racism, Anti-Semitism: A Dimension of Enlightenment Culture," The Languages of Psyche: Mind and Body in Enlightenment Thought (Berkeley, 1990), 405-43; Londa Schiebinger, "The Anatomy of Difference: Race and Sex in Eighteenth-Century Science," Eighteenth-Century Studies 23, no. 4 (Summer 1990): 387-405.

${ }^{70}$ Read's Weekly Journal, 9 September 1753; ibid., 6 October 1753. Moreover, it was argued, they would start competing with the English over employment.

${ }^{71}$ Ibid., 6 October 1753.
} 
on economic questions, they would have easily brought about the repeal of the bill. Enticing rich Jews to settle in England with their capital would create an external and artificial injection of money into the market. Far from enhancing the economy, it would harm it, causing a general rise in prices. Money by itself, detached from production, could not extend the commerce of any state nor weaken its rivals, as envisioned by the traditional mercantilist theories on which advocates of the bill relied. Moreover, an injection of money would encourage both the government and individuals to run further into debt, unbalancing the system. Rich immigrants were merely consumers with no productive benefit, and British policy should prioritize industrious working people. ${ }^{72}$

A similar emphasis was offered by Jonas Hanway, a merchant and philanthropist and a leading adversary pamphleteer who sought to differentiate between industrious and idle financial activities. It was not the system of public finance itself that was to blame, Hanway argued in contrast to other opponents to the bill, but the manner in which Jews employed it for gain- "the injurious practice of jobbing in stocks, and the supplying national demands by our submitting to the means of extortion." As public credit was meant to strengthen the state at moments of hardship, support of the debt should depend on "our own merchants and money-holders," who should take it as their national responsibility. Jews, as outsiders to the nation, could not be counted on in such moments, as was evident during the suppression of the Jacobite rebellion in 1745, when the intervention of English merchants prevented the execution of a "Jewish project" that "must have involved this nation much deeper in debt."73 Here again the notion of loyalty was central in the conception of the public credit system. Reliance on debt was not an anti-patriotic scheme, yet in order to secure its legitimate use, one had to ensure that only truly loyal citizens took part in it. Jews, though basically not disloyal, ${ }^{74}$ lacked a genuine commitment to society and state; this lack rendered their involvement in public credit suspicious and imperiling to national liberty, for they inclined to private interests rather than to communal ones. This difference in inclination had the power to "raise or depress us as a free nation." 75

According to Hanway, the essential reason for the rejection of the Jew Bill lay in Jews' incapacity to integrate into the English patriarchal social system, for they could never adopt the required social responsibility. Integration was a precondition for being a trustworthy investor in public finance and evidently also for holding land. Consequently, Jews' liberties should be restricted to the commercial sphere. ${ }^{76}$ Hanway tendentiously interpreted in this vein the opposition posture that, "so far from depressing the Jews, their opponents never meant to deprive them of any

\footnotetext{
72 Public Advertiser, 19 November 1753. The writer relates to Philo-Patriae's booklet, Considerations on the Bill to Permit Persons Professing the Jewish Religion to Be Naturalized by Parliament (London, 1753), 36-37.

73 Jonas Hanway, A Review of the Proposed Naturalization of the Jews... . (London, 1753), 73-74.

${ }^{74}$ Ibid., 98.

75 Ibid., 75-76.

${ }^{76}$ Ibid., chaps. 7 and 10.
} 
weight in their commercial capacity; but rather to keep from them every temptation which might divert them from so useful a pursuit."77

The distinction between Jewish productive commercialism and Jewish stockjobbing was reiterated in the London Evening Post the following year several months after the general elections, triggered by news that Prussia was encouraging immigration of traders of all nations and religions. It was assumed that such news might reignite the push for Jewish naturalization. The writer warned that one should attend to differences in the constitution of the two countries: Jews' usefulness in Prussia relied on the government of a "Philosopher" who would "take care that they shall never have there no Stock-Jobbing, no Funds, no publick Debts, to exercise the Industry of the Children of Israel; so that their Talents must be turned to Commerce." Echoing Barnard's arguments in the Commons, the writer argued that "where Trade is but in its Infancy, [Jews] may be made very useful under a wise Governor." However, as people in general were not as wise as their governors, the English "might in less than Half a Century be jostled or wheedled out of Religion, Liberty and Property, by the Introduction of a Swarm of rich Hebrews."78

The emphasis upon industriousness articulated by adversaries to the bill was not far from the emphasis made by the most important political-economic defender of the bill, the Reverend Josiah Tucker. Tucker perceived naturalization schemes in general and the Jewish naturalization in particular as efficient means for engaging monopolies and privileges, which he saw as remains of the tyrannic "Gothic" past. ${ }^{79}$ These obstacles hindered economic growth, which could be sustained only by free competition that would boost industriousness. Yet Tucker differed from adversaries such as Hanway in his notion of industry in two important aspects, as Jonathan Karp has demonstrated. First, Tucker regarded population increase as a substantial and crucial factor; and second, he regarded the Jews as adaptive people, not inherently inclined to unproductive financial schemes. ${ }^{80}$

\section{THE JEW BILL IN THE CONTEXT OF EIGHTEENTH-CENTURY NATURALIZATION DEBATES}

To return to the basic question regarding the Jew Bill: how unique was the episode in its wider political context? Was it only another Whig attempt in a string of naturalization bills? An apt example of partisan propaganda? Does it deserve examination as a distinct event? The common assessment, promoted by Perry, is that the polemic was simply a handy topic for rallying both parliamentary and public opposition against a

\footnotetext{
${ }^{77}$ It is telling that to some degree the practicality of Hanway's view was not so far from that of seventeenth-century Jewish apologists such as Luzzatto and ben Israel, as presented in Karp, The Politics of Jewish Commerce, 21-37.

${ }^{78}$ LEP, 1-3 October 1754

${ }^{79}$ On Tucker and the polemic, see Karp, The Politics of Jewish Commerce, 72-93; W. George Shelton, Dean Tucker and Eighteenth-Century Economic and Political Thought (New York, 1980), 79-87. Tucker was an eminent political-economic thinker and perhaps the non-governmental figure most identified with the Jewish cause, dubbed by the LEP as "Josiah ben Tucker ben Judas Iscariot" and the "Jew Chaplain of B[risto]l." For his account of his harassment by the LEP, see Josiah Tucker, An Humble Address and Earnest Appeal... . (Gloucester, 1775), 16n.

${ }^{80}$ Karp, Politics of Jewish Commerce, 72-91.
} 
Whig ministry in view of upcoming general elections. Such an understanding emphasizes the correlation of the Jew Bill with preceding naturalization bills, the most recent of which had been proposed, in vain, in 1746, 1747-48, and 1751. ${ }^{81}$ The Jew Bill, it was noted, was advocated by the same figures who promoted these earlier bills, and mostly it was opposed by similar parliamentarians-notably, apart from John Barnard who supported Protestant naturalization.

The Jew Bill, however, differed in significant points from the other bills of this type. It was the only bill designated solely for non-Christians; it was a bill with little practical significance; and it generated an unprecedented public clamor, undoubtedly one of the most forceful mobilizations of public opinion up to that point in the century. Other naturalization bills also received fierce parliamentary and public opposition, yet the rhetoric that characterized the Jew Bill polemic was profoundly different. While opposition to previous naturalization schemes relied on political-economic arguments, antagonism to the Jew Bill hinged upon religious reasoning - at times, as demonstrated, conflating the two into a political-economic perspective of religious identity and difference. ${ }^{82}$ These distinctions lent the discussion a social and cultural vigor that did not derive from partisan interests themselves and had independent life and influence. Another reason why the controversy resonated so strongly in the public sphere, I suggest, was the interrelation of the subject matter and concerns about public finance. Jews were good tools for thinking about economic matters, and in this particular case they emblematized the question of public finance. Unlike previous general naturalization attempts, the Jew Bill was aimed exclusively at wealthy Jews, and it was acknowledged that it arose solely in return of favor for Jewish magnates who had backed the government financially during the Jacobite rebellion. The recurrent argument for the measure was that it would provide capital for public funds. Consequently, the Jew Bill intersected central axes that preoccupied mid-eighteenth-century English society: the scope of religious toleration, economic improvement, the valuation of the post-financialrevolution market and its social effects, and the nature of citizenship. All these issues became intensified in the period between the War of Austrian Succession and the Seven Year's War. ${ }^{83}$

The Jew Bill's relationship with public finance introduced a new element into the series of controversies around naturalization bills and focused a spotlight on the nature of the new financial culture and its instruments. These questions were important to the way that Jews themselves were perceived, the polemic firmly linking them with the undecided social status of finance. The polemic was interwoven with common questions that had preoccupied the public in previous debates, but this time they were reshaped to reflect concerns around finance.

The first concern was that of economic productivity. While earlier naturalization debates considered the demographic and occupational aspects of the question broadly, the current debate focused the discussion on the economic productivity of

\footnotetext{
${ }^{81}$ For some background on these bills, all proposed by MP Robert Nugent, see Statt, Foreigners and Englishmen, 209-12.

${ }^{82}$ An initial comparison is offered in ibid., chap. 8; see also Salim Rashid, "Josiah Tucker, Anglican Anti-Semitism, and the Jew Bill of 1753," Historical Magazine of the Protestant Episcopal Church 51, no. 2 (June 1982): 191-201. However, a thorough comparative examination has yet to be conducted.

${ }^{83}$ Wilson, The Sense of the People, 185-205.
} 
trade in credit. This question hovered above the polemic and over the assessment of the productivity of the Jews and their potential contribution to English commerce. A writer in the Westminster Journal claimed that the Jewish money the bill would bring into England would improve nothing, for "money, or credit, circulating through a nation, from hand to hand, without producing labour and industry in the inhabitants, is direct gaming; and what else can be expected from the Jews, upon their naturalization."84 Another London Evening Post column, following a discussion of the Jew Bill, stated that "Men may be very active and busy, without being at all industrious; that the Labour of the Hands or Brain must be well directed to merit this Appellation; and that Dealing of Cards, or Shuffling of Stocks from Morning to Night, tho' it may be a gainful, is not an industrious, Employment." 85 Some adversaries emphasized the futility of trade in finance and claimed that Jews were preoccupied with such enterprise. "Britannicus" in the London Evening Post maintained that a Jewish economic contribution would be negligible, for Jews' commercial capability "is chiefly in the Stocks, and their arts of Merchandize are exerted principally in Exchange-Alley." Britannicus portrayed Jewish society as having a common economic characteristic: while the poor among them might cheat the public peddling counterfeit commodities, the wealthy grew rich not by trade in real commodities but by "State Jobbs, Lotteries, and other iniquitous Arts of Exchange-Alley," themselves forms of counterfeit commerce. ${ }^{86}$ Similarly, another writer argued that Jews "deal largely in the Mysteries and Iniquities of Stock-Jobbing, and get vast Estates by plundering the Publick." 87 Their professionalization in the dodgy arena of stock trade substituted for a total lack of productive abilities, or "real commerce," as Lord Egmont phrased it in the third reading of the bill, for Jews could neither toil the land nor engage in manufacture. As we have seen, these were recurrent themes in all opposition media: parliamentary polemic, the press, and pamphleteering. ${ }^{88}$ Advocates of the bill, on the other hand, emphasized the contribution of the public debt to national power and hence also to the growth of national economy, and the contribution of the Jews to the public fund. Yet the advocates too drew a line between a productive trade in credit and a harmful one, castigating the practice of speculative stockjobbing. Consequently, they sought to exonerate the Jews from this association repeatedly made by the bill's opponents. ${ }^{89}$

A second central theme in naturalization debates was political liberty. During the eighteenth century, the notion of liberty came to be profoundly related to commerce. Polemicists argued as to whether liberty was a precondition for free and thriving commerce or vice versa, yet all accepted the pivotal role of both in the growth and

${ }^{84}$ Quoted in Karp, Politics of Jewish Commerce, 89.

${ }^{85}$ LEP, 5-7 June 1753.

${ }^{86}$ LEP, 19-21 July 1753.

${ }^{87}$ LEP, 28-30 June 1753. The essay relates to the pamphlet The Bill Permitting the Jews to Be Naturalized by Parliament, Having Been Misrepresented... . (London, 1753).

${ }^{88}$ For more pamphlets dealing with these themes, see Hanway, A Review of the Proposed Naturalization, 70; Some Considerations on the Naturalization of the Jews ... by J. E. Gent. (London, 1753), 9, 11, 68-74; George Coningesby, The Jewish Naturalization Considered (London, 1753), 5-6. For more occurrences of such discussions in the press, see also LEP, 21-23 August 1753; Read's Weekly Journal, 20 October 1753.

${ }^{89}$ See, for instance, Philo-Patriae, Further Considerations, 36; An Earnest and Serious Address to the Freeholders and Electors of Great-Britain... . (London, 1753), 29-30. 
wellbeing of societies. By mid-century, the ideology of liberty reached an apotheosis, becoming the fulcrum of British identification by both Britons and foreigners. ${ }^{90}$ Predictably, it was a prevalent theme in the Jew Bill polemic, as it had been around previous naturalization schemes. The opposition repeatedly depicted the bill as a scheme that would lead to the enslavement of Britons by the Jews, and to the disintegration of all social and political institutions. This aspect has been extensively discussed in all accounts of the episode, and there is no need for reiteration here. Advocates of the bill replied with the same coin. The central obstruction of commerce, they argued, was superstitious intolerance; hence it was also a major impediment in the progress of liberty. Contra the opposition, they had to prove that Jews were capable of the civil qualities of liberty and so had to exonerate them from accusations of antinational and anti-social economic conduct. Jewish economic conduct, they often claimed, was not essentialist: Jews were not bound to specific economic activities and tended to adopt the manners characterizing their host countries. In England, these would include the "Love of Liberty and their Country." But the form of liberty promoted by advocates was inherently different from that employed by opponents. While opponents insisted on the intrinsic relation between British liberty and Christianity - a confessional liberty, as Justin Champion calls it —advocates of the bill promoted a notion of civil, non-confessional liberty. ${ }^{92}$ What mattered was not the denomination of a group but the civil implications of its doctrines; to a great degree, advocates argued, Judaism was closer to Protestantism and enhanced loyalty to the state more than did Catholicism and Dissent. ${ }^{93}$ Consequently, the attack on the Jews was an attack on British liberty that would encroach eventually on Christians' liberties. ${ }^{94}$

However, for opponents of the bill it was not only the Jews' religion that made them illegitimate as free citizens. As discussed above, most opponents claimed that public credit endangered political liberty by placing unlimited power in the hands of the government and by degrading social institutions. Jews, they argued, gained from this system of credit, enhanced it, and had an interest in its endurance. Like the Jews of old, who were employed by kings for financial backing while bypassing Parliament, thus forming a unit against the people-as elaborated by antiquarians who were commonly referred to by opponents 95 - the employment of public credit by contemporary Jews had the same anti-civil and corruptive effect.

${ }^{90}$ Statt, Foreigners and Englishmen, 218-19.

${ }^{91}$ Philo-Patriae, Further Considerations, 6-7.

92 Justin Champion, "Toleration and Citizenship in Enlightenment England: John Toland and the Naturalization of the Jews, 1714-1753," in Toleration in Enlightenment Europe, ed. Ole Peter Grell and Roy Porter (Cambridge, 2000), 133-56.

${ }_{93}$ Philo-Patriae, Considerations on the Bill; Edward Weston, Diaspora: Some Reflections upon the Question Relating to the Naturalization of Jews... . (London, 1754).

94 See, for example, Philo-Patriae, Further Considerations; Josiah Tucker, A Second Letter to a Friend Concerning Naturalizations... . (London, 1753); Some Thoughts on the Reasonableness of a General Naturalization: Addressed to Those of All Denominations Who Act upon Whig-Principles (London, 1753); T. F., "A Letter from a Clergyman in the Country, to His Friend in Town," in The Other Side of the Question. Being a Collection of What Hath Yet Appeared in Defence of the Late Act, in Favour of the Jews..., ed. Roger Flexman (London, 1753), 35-42.

${ }_{95}$ Most significant was William Prynne, A Short Demurrer to the Jewes Long Discontinued Remitter into England (London, 1656). 
Eighteenth-century naturalization bills were as a rule unsuccessful, ${ }^{96}$ and the fate of the 1753 Jew Bill was thus not exceptional. One piece of legislation, however, stood apart in this series of attempts and can serve as a foil for the 1753 polemic. The Plantation Act of 1740 allowed foreigners who had resided for seven years in the American colonies to naturalize without a parliamentary bill, and exempted Quakers and Jews from Christian oaths. This measure was designed to enhance British colonial trade in the Americas, especially against the nation's prospering Dutch rivals (who had already taken similar measures of naturalization in their colonies). Why did that bill pass without any agitation, in spite of the provisions it offered Jews, while the 1753 bill aroused unprecedented clamor? The difference, I suggest, resulted in part from the inner conflict embedded in a national empire relying on commerce. Distribution of citizenship enhanced the commercial networks essential for imperial expansion, yet it also entailed the sharing of national identity. Jews, like other marginalized sectors with commercial influence, posed a dilemma: by mid-eighteenth century, it was commonly acknowledged that Jews loomed large in the global commercial matrix of Britain and were valuable in its expansion, ${ }^{97}$ yet they were perceived as essentially alien. The option for naturalizing Jews in the colonies potentially allowed legislators to benefit from their commercial advantage while keeping the tension around questions of national identity at a distance. ${ }^{98}$ In contrast, it is plausible that the failure of the 1753 attempt to allow naturalization in the motherland owed much to its bringing the problem of national identity into the metropole. However, as this paper has sought to demonstrate, the 1753 polemic had another important feature that discussions on colonial naturalization in 1740 did not involve: concern over public credit. This issue related to the metropole rather to the colonies. Moreover, the 1740 legislation took place at an earlier stage of the consolidation of the association of Jews with public credit, while the events of 1753 occurred in a changed setting.

96 The 1709 Protestant Naturalization Act was repealed in 1712 after intense public clamor, being then the longest-lived achievement of naturalization in Britain.

${ }_{97}$ Rabin, chap. 1, in Britain and Its Internal Others; G. Yogev, Diamonds and Coral: Anglo-Dutch Jews and Eighteenth-Century Trade (New York, 1978); Stephen A. Fortune, Merchants and Jews: The Struggle for British West Indian Commerce, 1650-1750 (Gainesville, 1984); Harold Pollins, chap. 2, in Economic History of the Jews in England (Rutherford, NJ, 1982) 2.

${ }^{98}$ It is telling that the execution of the 1740 measure by local colonial administrations was far from compliant, resonating in many respects on both economic and religious grounds with the 1753 opposition discourse. Local English colonists, apparently, were much more concerned with questions of identity regarding their non-Anglican neighboring colonists than were parliamentarians and the public on the whole in the metropole. For valuable discussions on the tension of imperial expansion and citizenship, see Kathleen Wilson, chap. 1, in The Island Race: Englishness, Empire and Gender in the Eighteenth Century (New York, 2006); Jessica Roitman, "Creating Confusion in the Colonies: Jews, Citizenship, and the Dutch and British Atlantics," Itinerario 36, no. 2 (August 2012): 55-90. On the hardships of civil integration of Jews in the British colonies, see also C. S. Monaco, "Port Jews or a People of the Diaspora? A Critique of the Port Jew Concept," Jewish Social Studies 15, no. 2 (Winter 2009): 137-66; Godfrey and Godfrey, chap. 3, in Search out the Land. The latter work also offers an overview of the 1740 Act in relation to Jews in the British Americas. For a different perspective on British imperialism and the attitude towards Jews, focusing on the latter part of the century, see Eitan Bar-Yosef, "Green and Pleasant Lands': England and the Holy Land in Plebeian Millenarian Culture, c. 1790-1820," in $A$ New Imperial History: Culture, Identity, and Modernity in Britain and the Empire, 1660-1840, ed. Kathleen Wilson (Cambridge, 2004), 155-75. 


\section{CONCLUSION}

The previous section illustrated that the 1753 polemic over Jewish naturalization differed from preceding naturalization proposals in that it introduced distinct politicaleconomic questions, namely, concerns about the post-financial-revolution system. However, arguing for this distinctiveness again brings the problem of uniqueness to the fore: if the polemic hinged on the question of finance, in what sense was it different from earlier controversies over similar concerns characteristic of the eighteenth century? The question intensifies when one examines the rhetorical moves of the 1753 opposition in comparison with the social critique raised during the 1720 South Sea Bubble crisis, for example. In both cases, finance as opposed to Christian spirit, the role of Providence, and the relationship between political, social, and religious corruption generated by financial inclinations, among other motifs, were all employed. ${ }^{99}$ Was the economic anti-Jewish rhetoric of 1753 merely a reiteration of existing forms of social critique? This question is consequential for understanding the "Jewishness" of the polemic, still a point of debate among historians. If the issue of the new forms of finance was one of the reasons that the apparently minor question of Jewish naturalization evolved into such a vigorous polemic, as I have been suggesting, then whether the Jews have been merely incidental in a largely reiterated dispute becomes a substantial question.

To approach it, a general overview of both the eighteenth-century popular critique of finance and the financial anti-Jewish critique is in order. From the 1690s to the early nineteenth century, critique of the financial market and its expanding impact on British society and politics was fairly continuous but fluctuated in magnitude. It was expressed most intensely in the first decades of the Financial Revolution, from the 1690s to the 1720s, and moderated somewhat after the South Sea Bubble crisis had subsided without bringing in its wake the catastrophic collapse envisioned by many. That moderation resulted from two interrelated changes. The century saw a gradual and persistent increase in the social extent of participation in the financial market. By mid-century, broad social sectors were invested in the public debt via a range of securities. Consequently, the degree of respectability associated with finance grew, and public antipathy to it declined. ${ }^{100}$ At the same time, stockbroking was institutionalizing, mainly through brokers' own attempts for self-regulation. An initiative in 1761 to create an exclusive association with an annual fee and a code of conduct was unsuccessful, but it was eventually carried out in 1773 with the opening of a new building dedicated solely to trade in stocks. ${ }^{101}$ The growing acceptance of finance, along with growing interest in it, is

\footnotetext{
99 See, for example, Jonathan Sheehan and Dror Wahrman, chap. 3, in Invisible Hands: Self-Organization and the Eighteenth Century (Chicago, 2015).

${ }^{100}$ Stuart Banner, Anglo-American Securities Regulation: Cultural and Political Roots, 1690-1860 (New York, 2002), 94-95; John Brewer, The Sinews of Power, War, Money and the English State 16881783 (Cambridge, MA, 1988), 210; Peter Earle, The Making of the English Middle Class: Business, Society, and Family Life in London, 1660-1730 (Berkeley, 1989), 146-51; Paul Langford, A Polite and Commercial People: England, 1727-1783 (New York, 1994), 642.

${ }^{101}$ H. V. Bowen, "The Pests of Human Society': Stockbrokers, Jobbers and Speculators in Mid-Eighteenth-Century Britain," History 78, no. 252 (February 1993): 38-53, at 52-53; Dickson, The Financial Revolution, 506; Ranald C. Michie, The London Stock Exchange: A History (Oxford, 2001), 31; Sydney R. Cope, "Stock-Brokers Find a Home: How Stock-Exchange Came to Be Established
} 
evident in the success of a guide to the securities market, which was first of its kind. Every Man His Own Broker, or, A Guide to Exchange Alley by Thomas Mortimer, published in 1761, was in a fourth edition by the end of the year (and a fourteenth by 1807); ultimately it sold tens of thousands of copies and was translated into several languages. ${ }^{102}$

Remarkably, the figure of the Jew became prominent in the public discourse on finance only towards the middle of the century. During the public clamor of the South Sea Bubble crisis, for instance, the image of the Jew played only a side role in the discourse, ${ }^{103}$ and in early century drama and popular prints that were major vehicles for venting public grievance over the impact of the Financial Revolution. ${ }^{104}$ This is not to say that Jews were absent from this discourse, but rather that their minor significance in it had few reverberations. This situation changed around the middle of the century, when the figure of the Jew came to hold a prominent role in contemporary social criticism and eventually to embody the new financial system. From the 1740s, especially in drama, ${ }^{105}$ the figure of the "financial Jew" became increasingly visible in popular prints that dealt with the social ramifications of finance, a trend that intensified from the 1760s. ${ }^{106}$

Thus we see two contradictory trajectories, both shifting around mid-century. The association of Jews with modern financial vices was becoming commonplace. At the same time, public critique of the bourgeoning financial market seems to have declined, accompanied by a gentrification of financial activity. This latter change marked the acknowledgement that the new financial system was there to stay. Accordingly, there was no more point in rejecting the system altogether as was

in Sweetings Alley in 1773," Guildhall Studies in London History, no. 2 (1977): 212-19. The stockbrokers were not alone in undergoing a process of institutionalization at that time. London bankers set up the London Clearing House in 1773, and marine insurers set up the New Lloyds in 1774.

${ }^{102}$ S. R. Cope, "The Stock Exchange Revisited: A New Look at the Market in Securities in London in the Eighteenth Century," Economica 45, no. 177 (February 1978): 1-21, at 4.

103 The marginality in London of the image of the Jew in the public discourse on the South Sea Bubble crisis becomes fleshed out when compared with another major financial center affected by the crisis, Amsterdam; there the relative scope of transactions by Jews was about half of that in London (10 percent versus 20 percent), yet Jews were perceived in Dutch popular culture as the emblem and scapegoat of the crisis. See Margaret Jacob, "Was the Eighteenth-Century Republican Essentially Anticapitalist?," Republics of Letters: A Journal for the Study of Knowledge, Politics, and the Arts 2, no. 1 (December 2010): 11-20, at 15-19; Frans de Bruyn, "Reading Het Groote Tafereel Der Dwaasheid: An Emblem Book of the Folly of Speculation in the Bubble Year 1720," Eighteenth-Century Life 24, no. 2 (Spring 2000): 142. On the involvement of Jews in the securities market in 1720, see Ann M. Carlos, Karen Maguire, and Larry Neal, “A Knavish People... .': London Jewry and the Stock Market during the South Sea Bubble," Business History 50, no. 6 (November 2008): 728-48.

${ }^{104}$ Of the many plays that tackled the social environment of the financial revolution, only two related to Jews with some substantiality: Baron Lansdowne's The Jew of Venice (1701), which was an adaptation of Shakespeare's The Merchant of Venice, and Thomas Baker's Hampstead Heath (1705). Drama in the 1720s had no unique approach to Jews.

105 The increasing importance of the Jew as a social foil to Britishness is examined in Michael Ragussis, chap. 3, in Theatrical Nation. However, Ragussis overlooks the financial aspect of this constructed Jewish otherness and its function within eighteenth century British society.

106 The sketched depiction in this paragraph will be elaborated in a future publication. The present article is a part of a larger project in progress, provisionally entitled "The Notion of Jewishness and the Making of English Commercial Society," analyzing the role of the changing image of the Jews-and religious images in general-in the commercialization of early modern England. 
common early in the century. Increasing acceptance required a new differentiation between acceptable and unacceptable behaviors and players. ${ }^{107}$ It is in this context, I suggest, that the image of the Jewish stockjobber became a handy tool in social critique. By epitomizing the evils of the system, that image allowed the whitewashing of the new prevailing norms of English society.

I conjecture that a major trigger enhancing the linking of Jews with the social problems of the Financial Revolution around mid-century was a qualitative change in Jewish involvement in state finance in the 1740s, which gave shape in public imagery to a new "Jewish danger"-inherently related to the new prevailing financial tools. The War of the Austrian Succession (1742-1748) and the Jacobite Rising of $1745-46$ put the state in a need of vast amounts of credit, opening loan contracting beyond the circle of privileged MPs and City merchants. Several Jewish financiers, central among them Sampson Gideon, seized the opportunity. In almost every year through the 1740s, Gideon was active in managing a government loan. These activities, apart from enriching him tremendously, made him a prominent financial adviser to the government. ${ }^{108}$ Unlike contemporary court Jews on the Continent, who were financial managers to single rulers, Gideon operated at the center of a new system of governmental public finance that involved the broader political nation and broad sectors from the middle class upwards. As such, he attracted significant public attention and came to epitomize the political-economic vices of the age enmeshed with an alien identity-a volatile compound. ${ }^{109}$ The 1753 opposition discourse drew upon this developing association of Jews with finance, intersecting, as shown, with intense concerns regarding national virility, luxury, and the imperial project. Indeed, Jewish magnates initially lobbied for the Jew Bill as their due for past financial support. Ironically, Sampson Gideon starkly opposed it and against this backdrop eventually cut his ties with the Jewish community. That fact did not hinder opposition discourse from rendering his figure in an abundance of prints and satires as the emblem of the Jewish financial peril. ${ }^{110}$

Returning to the question at hand, the critique against the prevailing financial environment in 1753 and the earlier critique in 1720 exhibited similar rhetoric but also an essential difference: the 1720 discourse depicted the social perils of finance as evolving from within society, while the 1753 discourse ascribed them to an exterior factor-to the Jews, as contradicting the very nature of Britishness. The 1753 polemic, as it were, bolstered and consolidated the new association of Jews and

${ }^{107}$ Harriet Guest, “'These Neuter Somethings': Gender Difference and Commercial Culture in MidEighteenth-Century England," in Refiguring Revolutions: Aesthetics and Politics from the English Revolution to the Romantic Revolution, ed. Kevin Sharpe and Steven N. Zwicker (Berkeley, 1998), 173-94.

${ }^{108}$ Lucy Stuart Sutherland, "Samson Gideon: Eighteenth Century Jewish Financier," Transactions (Jewish Historical Society of England), no. 17 (1951): 79-90; Dickson, The Financial Revolution, 222-28, 230-36.

109 Publications such as The Art of Stock-Jobbing, a Poem. By a Gideonite (London, 1746); A Winter Evening's Conversation in a Club of Jews, Dutcmen [sic], French refugees, and English Stock-Jobbers (London, 1748); Arthur Murphy, "The Temple of Laverna," Gray's Inn Journal, 17 February 1752 [reprinted twice in 1753]; Adventures Under-Ground. A Letter from a Gentleman Swallowed Up in the Late Earthquake to a Friend on His Travels (London, 1750), 15-20, all bolstered his notoriety by describing Gideon's destructive effects on the nation as well as the perilous flaws of the new economic system itself. See also Rabin, chap. 1, in Britain and Its Internal Others.

${ }^{110}$ Felsenstein, Anti-Semitic Stereotypes, 206-9. 
the defects of the financial system to be further employed throughout the century. From this perspective, the argument often made that the Jew Bill had no historical impact is misleading. ${ }^{111}$ While the event did not trigger any change in the formal status of the Jews, it marked a new representation of their relation with British society.

${ }^{111}$ Cecil Roth in A History of the Jews in England, 3rd ed. (Oxford, 1964), 222-23, claimed that the event "left behind no rancour." See also Perry, Public Opinion, 76-77; Katz, The Jews in the History of England. 